\title{
Adam FILUS
}

Uniwersytet Jagielloński

filadam@wp.pl

\section{STOSUNEK RZĄDU AUSTRALII DO NIELEGALNEJ MIGRACJI W LATACH 1996-2018 ${ }^{1}$}

\section{ABSTRACT Australian Governments' Stance on Illegal Immigration in 1996-2018}

Australia is well known for its strict immigration policy. It results from the country's constant struggle with the flow of illegal migrants, brought to Australian shores through human smuggling. The author analyses immigration policies of five Prime Ministers representing two major Australian parties: the Liberal Party of Australia and the Australian Labor Party. Starting with the premiership of John Howard (1996-2007), and ending with Malcolm Turnbull's era (2015-2018), the author examines the situation of illegal immigrants in Australia and changes in immigration and asylum policies.

KEYWORDS immigration policy, Australia, Pacific Solution, sovereign borders, asylum seekers

1 Niniejszy artykuł stanowi fragment pracy licencjackiej autora, obronionej w Instytucie Nauk Politycznych i Stosunków Międzynarodowych Uniwersytetu Jagiellońskiego w lipcu 2018 r., zatytułowanej Analiza restrykcyjnej polityki imigracyjnej Australii na przyktadzie sytuacji nielegalnych imigrantów. Promotorem pracy była dr Agnieszka Czubik, a recenzentem dr Agnieszka Nitszke. 


\section{WSTĘP}

Australia jest znana ze swojej restrykcyjnej polityki imigracyjnej. Wynika to ze zmagań tego państwa z napływem nielegalnych imigrantów sprowadzanych przez przemytników. Ich droga do Australii jest bardzo niebezpieczna i często kończy się tragicznie. Od 2001 r. w Australii obowiązują dwa programy imigracyjne, które mają jedno zadanie: zatrzymać łodzie przemytników (stop the boats). Powstały obozy dla nielegalnych imigrantów, a marynarka australijska kontroluje wybrzeże i zatrzymuje łodzie z nimi na pokładzie. Stanowisko Australii często spotyka się z brakiem zrozumienia społeczności międzynarodowej. Samo australijskie społeczeństwo bywa przecież nazywane spoteczeństwem migrantów. Rząd w Canberze odrzuca zarzuty o łamanie praw człowieka w związku z tworzeniem obozów i odsyłaniem nielegalnych imigrantów do Indonezji. Problem jednak istnieje.

W artykule zanalizowana zostanie polityka jedenastu rządów działających w latach 1996-2018. Tworzyły ją dwie najważniejsze australijskie partie: Liberalna Partia Australii (Liberal Party of Australia, LP), która rządziła wraz z Narodową Partią Australii (National Party of Australia, NPA)², i Australijska Partia Pracy (Australian Labor Party, ALP). W tym okresie urząd sprawowało pięciu premierów: John Howard (1996-2007, LP), Kevin Rudd (2007-2010 i 2013, ALP), Julia Gillard (20102013, ALP), Tony Abbott (2013-2015, LP) i Malcolm Turnbull (2015-2018, LP). Celem jest zbadanie ewolucji podejścia do nielegalnych migracji na przestrzeni lat. Sformułowano dwa główne pytania badawcze: W jaki sposób w latach 1996-2018 rządy Australii postrzegały nielegalną imigrację? Czy podejście do problemu uległo zmianie na przestrzeni ostatnich 20 lat? Artykuł przygotowano, używając metody historycznej i konstrukcji chronologicznej. Wykorzystano literaturę źródłową (m.in. publiczne wystąpienia australijskich polityków) i przedmiotu (m.in. prace poświęcone historii i kulturze Australii), a także materiały prasowe. Wszystkie tłumaczenia tekstów anglojęzycznych w niniejszym artykule pochodzą od autora.

\section{RZĄDY JOHNA HOWARDA (1996-2007). „JEDNA AUSTRALIA”}

W latach 90. XX w. w australijskich mediach toczyła się debata dotycząca wpływu różnorodności etnicznej na społeczeństwo, przestrzegania praw człowieka i tego, czy Australijczycy życzą sobie napływu imigrantów. Od lat 70. nie brakowało przeciwników wielokulturowości, jednak przez dwie dekady próbowano przekonać ich do zmiany zdania. Koalicyjny rząd ALP-NPA usiłował skłonić przybywających imigrantów do osiedlania się w mniejszych miastach, jednak nie przyniosło to skutku³. W 1996 r. ster rządu objął John Howard, przeciwnik polityki wielokulturowości. Spowodowało to rozpropagowanie sformułowanego przed laty przez ALP konceptu „Jednej Australii”

Obie partie tworzą blok nazywany popularnie „Koalicją” (the Coalition).

3 M. Wrona, Imigracja a gospodarka. Doświadczenia Australii, Warszawa 2016, s. 158. 
(„the One Australia”) ${ }^{4}$. W opublikowanym w 1988 r. dokumencie przedstawiono jego główne tezy, do których należało zakończenie wdrażania polityki wielokulturowości i ograniczenie azjatyckiej imigracjis.

Po wygranych przez ALP wyborach z listopada 2001 r. Howard podjął decyzję o zamknięciu instytucji federalnych zajmujących się wielokulturowością i zmniejszeniu wydatków na podobne cele ${ }^{6}$. Premier zdecydował się na szereg radykalnych zmian: zmniejszył limity imigracyjne, ograniczył zakres opieki społecznej dla nowo przybyłych imigrantów i skoncentrował na obniżaniu kosztów imigracji. Dlatego zaprzestano wypłacania zasiłków i innych świadczeń w okresie dwóch pierwszych lat od przybycia do Australii. Zlikwidowano też możliwość ubiegania się przez nielegalnych imigrantów o Austudy, czyli stypendium rządowe dla zagranicznych studentów. Jednocześnie władze postanowiły zwiększyć liczbę wykwalifikowanych imigrantów, szczególnie z sektora informatycznego. Wprowadzono ułatwienia w otrzymaniu wizy stałego pobytu dla absolwentów kierunków inżynierskich i ekonomicznych ${ }^{7}$. Za wielki sukces uznano ograniczenie programu łączenia rodzin, który generował wysokie koszty dla państwa. Oprócz tego powrócono do testów językowych i uniemożliwiono sponsorowanie pobytu współmałżonkom (przybywający musiał wykazać swoją wypłacalność $)^{8}$. Działania Howarda zmniejszyły liczbę przyznanych wiz. W kategorii łączenia rodzin w latach 1996-1999 ich liczba spadła z 56,7 tys. do 32 tys. ${ }^{9}$ Wzrosła liczba wydawanych wiz biznesowych lub czasowych, których ograniczenia rządowe nie dotyczyły. Pozwalały one na pobyt krótkoterminowy, czyli na okres do 12 miesię$\mathrm{cy}^{10}$. Za pomocą wiz biznesowych rząd dążył do zwiększenia liczby pracowników, których sponsorami mieli być zainteresowani pracodawcy. Wdrażanie polityki „Jednej Australii" jednoznacznie oznaczało odejście od prowadzonej od lat 70. XX w. polityki wielokulturowości ${ }^{11}$.

Swojej twardej postawy wobec nielegalnych imigrantów premier dowiódł w 2001 r., kiedy azjatyccy uchodźcy próbowali przedostać się drogą morską na terytorium Australii. Społeczeństwo australijskie poparło działania Howarda mające na celu niewpuszczenie boat people ${ }^{12}$. Wcześniej widoczny był spadek popularności rządu, a ALP poniosła porażkę w wyborach uzupełniających i stanowych. Dzięki sprawie nielegalnych imigrantów ALP zwyciężyła jednak we wspomnianych wyborach federalnych w $2001 \mathrm{r}^{13}$

\footnotetext{
Tamże, s. 158-159.

Tamże.

J. Lencznarowicz, Australia, Warszawa 2005, s. 391.

M. Wrona, Imigracja a gospodarka..., s. 160-161.

J. Lencznarowicz, Australia..., s. 391.

M. Wrona, Imigracja a gospodarka..., s. 160.

Tamże.

Tamże, s. 159-160.

12 J. Lencznarowicz, Australia ..., s. 399.

13 Tamże, s. 397-398.
} 
W wyborach 2004 r. Howard był przedstawiany jako przywódca godny zaufania, zasłużony dla rozwoju gospodarczego i walczący z terroryzmem. Dzięki zwycięstwu w tych wyborach został drugim najdłużej urzędującym premierem w historii Australii ${ }^{14}$. Zwycięstwo w wyborach 2004 r. umożliwiło mu wprowadzenie radykalnych zmian dotyczących nielegalnych imigrantów próbujących znaleźć pracę na rynku australijskim ${ }^{15}$. Polityka imigracyjna Howarda była nazywana polityka podchwytli$w a$, ponieważ zmierzała do jednoczesnego ograniczenia nielegalnej imigracji poprzez Rozwiązanie pacyficzne (Pacific Solution, zob. poniżej) i zwiększenia imigracji legalnej pracowników wykwalifikowanych. Spotkało się to z poparciem zarówno pracowników, jak i pracodawców ${ }^{16}$.

\subsection{Rozwiązanie pacyficzne (2001-2007)}

W 2001 r. miało miejsce kilka wydarzeń, które wzmocniły pozycję Howarda. Między innymi podjęto wówczas decyzję o przenoszeniu zatrzymanych na morzu osób ubiegających się o azyl do państw trzecich ${ }^{17}$. Szczególne znaczenie miała sprawa statku Tampa. W sierpniu $2001 \mathrm{r}$. ten norweski frachtowiec uratował z pokładu tonącej na Oceanie Indyjskim łodzi 450 Afgańczyków, którzy zmierzali ku wybrzeżu Australii. Kapitan statku nie uzyskał pozwolenia na wpłynięcie do portu na będącej zamorskim terytorium Australii Wyspie Bożego Narodzenia. Pomimo nacisków społeczności międzynarodowej Howard pozostał nieugięty. Gotowość do przyjęcia Afgańczyków ogłosiła m.in. Nowa Zelandia. Premier uznał wydarzenie za swój wielki sukces. Od tego momentu zaczął forsować takie podejście do sprawy, zawierał także umowy dwustronne, pozwalające na przekazywanie migrantów z terytorium Australii do innych państw ${ }^{18}$. Tak powstała polityka Pacific Solution, której nazwę tłumaczy się w Polsce najczęściej jako Rozwiązanie pacyficzne. Należy zwrócić uwagę, że określenie pacific może oznaczać także pokojowy lub pokojowo nastawiony.

Ochrona granic przed napływem osób poszukujących azylu („poszukiwaczy azylu” asylum seekers $)^{19}$ stała się częścią wspomnianej powyżej kampanii wyborczej w $2001 \mathrm{r}$. Premier wypowiedział wtedy powtarzane w wielu mediach słowa: My zdecydujemy, kto

14 Tamże, s. 398.

15 Tamże.

16 M. Wrona, Imigracja a gospodarka..., s. 165.

17 J. Phillips, The 'Pacific Solution' revisited: a statistical guide to the asylum seeker caseloads on Nauru and Manus Island, strona internetowa parlamentu australijskiego, [online] https://www.aph.gov.au/ about_parliament/parliamentary_departments/parliamentary_library/pubs/bn/2012-2013/pacificsolution, 21 III 2018.

18 S. Hiscock, Nauru and the Pacific Solution, "The Courier” 2002, no. 190, January-February, s. 21-22.

19 „Poszukiwacz azylu” (asylum seeker) to osoba poszukująca międzynarodowej ochrony, która nie uzyskała jeszcze ostatecznej decyzji o otrzymaniu jej w państwie, w którym złożyła wniosek. Zob. E. Karlsen, J. Phillips, E. Koleth, Seeking asylum: Australia's humanitarian program, s. 25, strona internetowa parlamentu australijskiego, [online] http://www.aph.gov.au/binaries/library/pubs/bn/sp/ seekingasylum.pdf, 19 III 2018. 
przyjedzie do tego panstwa, i w jakich okolicznościach ${ }^{20}$. Wybory miały miejsce 10 listopada 2001 r., dwa miesiące po zamachu na World Trade Center. Howard wykorzystał zaistniałą sytuację i ogłosił zamknięcie granic dla boat people, których od 1999 r. największa liczba przybywała z Bliskiego Wschodu. Argumentował to koniecznością zabezpieczenia Australii przed napływem potencjalnych terrorystów. W jednym z przemówień stwierdził, że zamach w Stanach Zjednoczonych dotyczył także Australii, ponieważ zaatakowane zostały wartości respektowane przez społeczeństwo australijskie ${ }^{21}$.

Jednak wojna $\mathrm{z}$ terroryzmem była tylko zasłoną dymną dla wprowadzenia restrykcyjnej polityki migracyjnej. Świadczy o tym podpisanie z rządami wyspiarskich państw Nauru i Papui-Nowej Gwinei memorandów tworzących podstawę prawną do transportowania osób poszukujących azylu, próbujących przedostać się do Australii ${ }^{22}$. Zgodnie z porozumieniami na obszarach tych wysp powstały tzw. centra detencyjne (detention centers). Miały być one miejscami zamieszkania imigrantów oczekujących na weryfikację wniosków azylowych. Umowę z Nauru podpisano na dzień przed atakami w Nowym Jorku, natomiast z rządem Papui-Nowej Gwinei - w dniu 11 października $2001 \mathrm{r}^{23}$ Ochrona granic przed napływem Afgańczyków nie mogła spotkać się $\mathrm{z}$ inną niż przychylna reakcją społeczeństwa. Wybrzeże było kontrolowane przez australijskich żołnierzy marynarki wojennej, upoważnionych do kierowania nielegalnych imigrantów do obozów przejściowych na wyspach Nauru i Manus (wyspie należącej do Papui-Nowej Gwinei ${ }^{24}$. Zgodnie z podpisanymi memorandami osoby poszukujące azylu mogły przebywać w obozach przejściowych do momentu rozpatrzenia ich wniosku azylowego, co miało trwać nie dłużej niż pół roku². Przyznanie wizy osobom oczekującym na rozpatrzenie ich sprawy nie było oczywiście gwarantowane. Początkowo polityka rządu obejmowała kontrolowanie terenów przybrzeżnych w poszukiwaniu nadpływających łodzi z uchodźcami. Z czasem wojsko zatrzymywało łodzie daleko od wybrzeży Australiii ${ }^{26}$. Prowadzona przez rząd polityka strachu przed nielegalnymi imigrantami z Bliskiego Wschodu zjednywała mu poparcie społeczne ${ }^{27}$.

20 John Howard's 2001 Election Policy Speech, kanał Malcolma Farnswortha, 22 II 2013, [online] https:// www.youtube.com/watch?v=FxlunUpz-Nc\&t=876s, 19 III 2018.

21 F. Broom, Has the 'Pacific Solution' solved anything in Australia?, Al-Jazeera, 3 IV 2014, [online] https://www.aljazeera.com/indepth/opinion/2014/03/pacific-solution-solved-austral-20143311 3844238975.html, 19 III 2018.

22 M. Krakowiak, Droga do wielokulturowości - polityka migracyjna Australii, „Biuletyn Migracyjny”, [online] http://biuletynmigracyjny.uw.edu.pl/33-s-luty-2012/droga-do-wielokulturowosci-polityka-migracyjna-australii, 12 II 2018.

23 F. Broom, Has the 'Pacific Solution'...

24 J. Phillips, The 'Pacific Solution' revisited...

25 Adrift in the Pacific: the Implications of Australia's Pacific Refugee Solution, Oxfam, II 2002, [online] https://web.archive.org/web/20041014060834/http://www.oxfam.org.au/campaigns/refugees/pacificsolution/, 21 III 2018.

26 Żaden imigrant nie chce tam trafić. Recepta $z$ Antypodów na problem z uchodźcami, Forsal.pl, 8 II 2016, [online] http://forsal.pl/artykuly/921734,jak-australia-radzi-sobie-z-uchodzcami-czy-to-recepta-na-problemy-ue.html, 19 III 2018.

27 F. Broom, Has the 'Pacific Solution'... 
Centra znajdowały się w znacznym oddaleniu od Australii. Odległość pomiędzy Canberrą a miastem Yaren, pełniącym funkcję nieoficjalnej stolicy Nauru, wynosi w linii prostej ok. 4,3 tys. $\mathrm{km}$. Lorengau, najważniejsze miasto na wyspie Manus, znajduje się nieco bliżej - ok. 3,7 tys. km od stolicy Australii. Dla porównania podobne odległości musieliby pokonać turyści chcący dostać się z Krakowa do Arabii Saudyjskiej (ok. 3,7 tys. km) lub zamierzający odwiedzić afrykańskie Mali (ok. 4,2 tys. $\mathrm{km})^{28}$. Do ich stworzenia rząd Australii wykorzystał czynniki historyczny i gospodarczy. Wyspa Nauru pozostawała pod administracją Australii aż do 1968 r., natomiast Papua-Nowa Gwinea była kolonią australijską aż do 1975 r. ${ }^{29}$ Rząd znał dobrze ich sytuację gospodarczą. Nauru uznawana była już wtedy za upadającą gospodarkę. W latach 1911-1968, ze względu na złoża fosforanu, była to najbogatsza wyspa na świecie, jednak po pół wieku eksploatacji uległy one wyczerpaniu, co spowodowało głęboki kryzys gospodarczy ${ }^{30}$. Rząd w Canberze obiecał więc Nauru pomoc finansową w zamian za przyjmowanie imigrantów. Natomiast wyspa Manus postrzegana była jako miejsce odosobnienia, z którego nie da się uciec ze względu na rozległą dżunglę. Według relacji imigrantów, którzy się na niej znaleźli, nie byto tam nic oprócz drzew i dżungli ${ }^{31}$. Wedle pogłosek mieszkańcy wyspy mieli być kanibalami $^{32}$. Do 2002 r. Papua-Nowa Gwinea i Nauru otrzymały od Australii prawie 50 mln AUD za przyjęcie ok. 2,2 tys. asylum seekers z Afganistanu, Iraku i Sri Lanki ${ }^{33}$. Australijskie pieniądze odegrały ważną rolę w gospodarce wyspiarskiego Nauru ${ }^{34}$. Większość osób próbujących dostać się na terytorium Australii trafiła do obozów przejściowych na Manus i Nauru na przełomie 2001 i 2002 r. ${ }^{35}$ Ich pobytem zainteresowały się organizacje pozarządowe, które podjęły badania nad konsekwencjami przebywania w ośrodkach. Okazało się, że pobyt miał poważny, negatywny wpływ na zdrowie psychiczne imigrantów. Ci ostatni podejmowali strajki głodowe, dochodziło też do przypadków samookaleczenn' ${ }^{36}$. Według oficjalnych danych w 2002 r. do Australii dopłyną tylko jeden nielegalny imigrant; reszta została wcześniej zatrzymana i przetransportowana do centrów ${ }^{37}$.

Rozwiązanie pacyficzne krytykowano nie tylko za nieskuteczność, ale także za to, że było bardzo kosztowne. Zgodnie z opublikowanym w 2007 r. raportem wysokość wydatków rządu na stworzenie obozów i transport imigrantów na wyspy szacowano

28 Dane podane za stroną internetową wyliczającą odległości między państwami Dystans.org, [online], http://www.dystans.org/Krak\%C3\%B3w/Mali, 21 III 2018.

Adrift In The Pacific Solution: the Implications of Australia's Pacific Refugee Solution...

30 S. Hiscock, Nauru and the Pacific Solution...

31 Film dokumentalny Chasing Asylum, reż. E. Orner, Australia 2016.

32 Tamże,

33 S. Hiscock, Nauru and the Pacific Solution...

34 Tamże.

35 J. Phillips, The 'Pacific Solution' revisited...

36 S. Hiscock, Nauru and the Pacific Solution...

37 M. Wrona, Imigracja a gospodarka..., s. 163. 
na ok. 1 mld USD ${ }^{38}$. Bardziej opłacalne byłoby przyjęcie nielegalnych imigrantów do Australii, ale czynnika finansowego nie uznawano za najważniejszy. Szacuje się, że w samych tylko latach 2001-2002 rząd w Canberze wydał 292 mln EUR na funkcjonowanie Rozwiązania pacyficznego. Za równowartość tej kwoty można było wybudować każdemu z 450 imigrantów ze statku Tampa dom w Australiii ${ }^{39}$.

\section{RZĄDY AUSTRALIJSKIEJ PARTII PRACY (2007-2013)}

\subsection{Rządy Kevina Rudda (2007-2010, 2013). Dalsze losy Rozwiązania pacyficznego}

W wyborach parlamentarnych 2007 r. zwycięstwo odniosła druga największa partia w Australii - Australijska Partia Pracy na czele z Kevinem Ruddem. W tym okresie widoczna była zmiana nastawienia społeczeństwa do nielegalnych imigrantów. W swojej kampanii wyborczej Rudd obiecał zakończenie Rozwiązania pacyficznego, co spotkato się z entuzjastycznym odbiorem ${ }^{40}$. Dużą rolę odegrały media informujące o sytuacji w obozach przejściowych. Pojawiało się coraz więcej reportaży, relacji świadków i statystyk, do czego przyczyniły się organizacje pozarządowe. Wszystko to uświadomiło społeczeństwu, na czym polega problem. Miała go rozwiązać zmiana na stanowisku premiera ${ }^{41}$. Rząd ALP rozpoczął działania mające na celu zmniejszenie restrykcji wobec boat people i osób przebywających w centrach detencyjnych. W lutym 2008 r. polityka Rozwiązania pacyficznego została zakończona.

W ministerialnym komunikacie prasowym podano wówczas, że w latach 2001-2008 w placówkach na Nauru i Manus znajdowało się ok. 1,6 tys. osób, w tym 786 Afgańczyków, 684 Irakijczyków i 88 obywateli Sri Lanki. Spośród nich około 61\% (705osób) zostało przesiedlonych do Australiií2 ${ }^{4}$. Osoby przebywające w obozach, które zostały uznane za niestwarzające zagrożenia dla społeczeństwa, mogły oczekiwać na rozstrzygnięcie sprawy ich statusu na terytorium Australiii ${ }^{43}$. Zakończenie Rozwiązania pacyficznego spowodowało natychmiastowy wzrost liczby asylum seekers ${ }^{44}$. Okres siedmiu lat jego obowiązywania nie wpłynął na zmniejszenie zainteresowania Australią. Ze względu na ciągły napływ imigrantów Kevin Rudd nie zlikwidował obozów detencyjnych ${ }^{45}$. Cały czas przebywali

\footnotetext{
38 J. Phillips, The 'Pacific Solution' revisited...

39 S. Hiscock, Nauru and the Pacific Solution...

40 M. Krakowiak, Droga do wielokulturowości...

41 Informacja pochodzi z przeprowadzanego przez autora wywiadu z obywatelką Australii. A. Filus, Analiza restrykcyjnej polityki imigracyjnej Australii na przyktadzie sytuacji nielegalnych imigrantów, praca licencjacka, Kraków 2018, s. 105-108.

42 J. Phillips, The 'Pacific Solution' revisited...

43 M. Wrona, Imigracja a gospodarka..., s. 165.

44 Tamże.

45 Tamże.
} 
tam imigranci szczególnie niebezpieczni, a także ci, którzy wielokrotnie naruszali procedury wizowe ${ }^{46}$.

Tak szybki wzrost liczby nielegalnych imigrantów próbujących dostać się do Australii nie był czymś, czego się spodziewano. Pomimo wykazania się większą niż jego poprzednik otwartością na uchodźców Rudd zastosował pewne ograniczenia dotyczące nielegalnych imigrantów z Afganistanu i Sri Lanki ${ }^{47}$. Postanowił, że wnioski o azyl składane przez osoby pochodzące z tych państw nie będą rozpatrywane po 9 kwietnia 2010 r. ze względu na to, że sytuacja w nich zaczęła się stabilizować. Także w kwietniu 2010 r. Rudd zapowiedział otwarcie czasowego obozu w zachodniej Australii. Do zamknięcia w 2002 r. Curtin Immigration Reception and Processing Centre było najgorszą pod względem warunków placówką tego rodzaju. Od 2010 r. w centrum przebywają nieposiadający rodzin mężczyźni, którzy próbowali dostać się do Australii bez wizy $^{48}$. Mimo tych działań rządu sytuacja nie uległa poprawie. W 2008 r. do Australii przybyło 161 boat people. W 2009 r., czyli po zakończeniu Rozwiązania pacyficznego, liczba ta wzrosła do 2,7 tys., natomiast w 2010 r. - do 6,5 tys. ${ }^{49}$ Rudd miał problemy z wywiązywaniem się z obietnic wyborczych, decyzje dotyczące m.in. ograniczenia liczby boat people przyczyniły się do osłabienia jego pozycji. W czerwcu 2010 r. ogłosił rezygnację ze stanowiska przewodniczącego partii i szefa rządu ${ }^{50}$.

Rudd powrócił do władzy na niecałe trzy miesiące w 2013 r. Poparł wtedy działania swojej poprzedniczki, Julii Gillard, która stała na czele rządu w latach 20102013, a mianowicie otwarcie obozów przejściowych. Rudd podpisał też umowę z rządem Papui-Nowej Gwinei, sprzeczną z poglądami, które głosił w 2007 r. Rząd australijski zapłacił $400 \mathrm{mln}$ AUD za działanie obozu przejściowego na wyspie Manus i za możliwość przesiedlania do niego migrantów próbujących dostać się do Australii ${ }^{51}$.

\subsection{Rządy Julii Gillard (2010-2013). Rozwiązanie malezyjskie}

Miejsce Rudda zajęła Julia Gillard, pierwsza kobieta na stanowisku premiera Australii. Wcześniej pełniła funkcję ministra ds. imigracji w gabinecie cieni, dlatego sprawa azylantów była dla niej priorytetem. W październiku 2010 r. premier zapowiedziała otwarcie dwóch obozów w południowej i zachodniej Australii dla 2 tys. kobiet i dzieci. 15 grudnia 2010 r. w okolicach Wyspy Bożego Narodzenia rozbiła się łódź z 50 imigrantami próbującymi dostać się do Australiii ${ }^{2}$. Odpowiedzialnością za

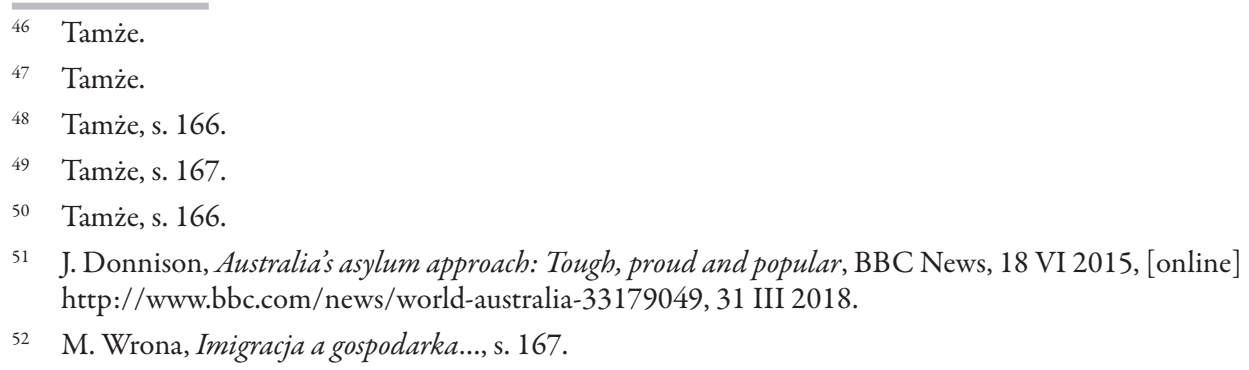


tę tragedię obarczono rząd, który swoją polityką imigracyjną przyczynił się do wzrostu liczby osób przybywających do Australii. W odpowiedzi na to wydarzenie Julia Gillard przedstawiła nową politykę dotyczącą boat people - Rozwiązanie malezyjskie (Malaysian Solution). W maju 2011 r. ogłoszono, że Australia finalizuje rozmowy z Malezją jako państwem trzecim, do którego miałyby być transportowane osoby poszukujące azylu. Ówczesny minister imigracji i obywatelstwa Chris Bowen twierdził, że rozmowy są bardzo zaawansowane. Jednak do sfinalizowania wymiany 800 boat people na 4 tys. imigrantów, którzy uzyskali status uchodźców w Malezji, nie doszło. Powodem była decyzja Sądu Najwyższego Australii stwierdzająca, że transport ludzi do Malezji jest niezgodny z prawem. Dodatkowo sąd nakazał przyjęcie do Australii 4 tys. uchodźców z Malezji ${ }^{53}$.

Te wydarzenia spowodowały powrót rządu do poprzednich wzorców. W 2012 r. Gillard ogłosiła ponowne otwarcie obozów na wyspach Nauru i Manus ${ }^{54}$. Zmiana wizji polityki imigracyjnej była widoczna w przemówieniu Gillard z 2013 r. Wytłumaczyła wtedy, co skłoniło ją do zastanowienia się nad dotychczasową polityką wobec asylum seekers. Zdecydowała się wzmocnić ochronę granic Australii ze względu na chęć zwalczania przemytu ludzi, ale także ze względu na rosnącą liczbę utonięć u brzegów Australii. Starała się podważyć słowa lidera opozycji, największego rywala w wyborach 2013 r. i późniejszego premiera Australii, Tony’ego Abbotta, który już wtedy głosił chęć zawracania łodzi do państw, z których wyruszyły ${ }^{55}$. Uważała, że takie działanie nie rozwiąże problemu, może go tylko spotęgować. Łodzie, których używają boat people, są bardzo niskiej jakości, często bywają przeładowane, co grozi ich zatonięciem ${ }^{56}$. Gillard nie zgłaszała postulatu całkowitego zamknięcia granic dla imigrantów. W przemówieniu wyraziła nadzieję, że Australijczycy będą otwarci na migrantów ${ }^{57}$. Stwierdziła również, że ponowne otwarcie obozów dla uchodźców na Nauru i Manus nie powinno być uznane za odnowienie Rozwiązania pacyficznego ${ }^{58}$. W stosunku do okresu rządów Johna Howarda liczba osób przybywających nielegalnie do Australii na łodziach dramatycznie wzrosła. To spowodowało też zwiększenie liczby utonięc ${ }^{59}$. O zmianie sposobu postrzegania nielegalnych imigrantów przez ALP świadczy wypowiedź Gillard z 2013 r. ${ }^{60}$ Premier tłumaczyła, że jej stanowisko wynika z chęci walki z przemytnikami

53 Tamże, s. 168.

54 Tamże, s. 166-168.

55 Full transcript: Gillard's asylum policy speech, SBS News, 23 VIII 2013, [online] https://www.sbs.com. $\mathrm{au} /$ news/full-transcript-gillard-s-asylum-policy-speech, 30 III 2018.

56 Tamże.

57 Tamże.

58 Tamże.

59 P. Reith, Gillard can run, but she can't hide from Nauru backflip, ABC News, 26 XII 2011, [online] http://www.abc.net.au/news/2011-12-27/reith---gillard27s-half-arsed-nauru-back-flip/3748020, 28 III 2018.

60 Gillard mówiła wtedy: Mam informację dla osób poszukujących azylu - nie ryzykujcie, nie oddawajcie swoich pieniędzy przemytnikom, ponieważ nie będziecie zyć w lepszych warunkach. Film dokumentalny Chasing Asylum... 
zarabiającymi na migrantach ${ }^{61}$. Uważała też, że polityka zawracania todzi (turning back the boats) jest niebezpieczna i nie gwarantuje rozwiązania problemu ${ }^{62}$.

Jak już wspomniano, w czerwcu 2013 r. na krótko na stanowisko premiera powrócił Kevin Rudd, którego zadaniem było poprowadzenie ALP do zwycięstwa we wrześniowych wyborach. W tym okresie przedstawił odmienną od tej głoszonej jeszcze trzy lata wcześniej wersję polityki imigracyjnej. Premier mówił, że osoby, które przybędą do Australii nielegalnie, nigdy nie otrzymaja zgody na osiedlenie się ${ }^{63}$. Jego stanowisko było więc zbieżne ze stanowiskiem Gillard i podobne do krytykowanego niegdyś Rozwiązania pacyficznego. W wyborach 2013 r. ALP poniosła porażkę, a do władzy powróciła koalicja LPA-NPA z Tonym Abbottem na czele.

\section{RZĄDY LIBERALNEJ PARTII AUSTRALII I NARODOWEJ PARTII AUSTRALII (2013-2018). OPERACJA SUWERENNE GRANICE}

\subsection{Rząd Tony'ego Abbotta w latach 2013-2015}

Polityka imigracyjna Tony'ego Abbotta opierała się na opanowaniu masowej imigracji do Australii. Jej wizję przedstawił już w 2010 r. Mówił wtedy o zawracaniu łodzi nielegalnych imigrantów do państw ich pochodzenia i zmniejszeniu utonięć w australijskich wodach $^{64}$. Zwycięstwo w wyborach 2013 r. zapewnił sobie, głosząc "twardą politykę" (hard-line policy) względem osób poszukujących azylu ${ }^{65}$. W 2013 r. do Australii przybyło 300 łodzi z nielegalnymi imigrantami. Po roku urzędowania Abbotta na stanowisku premiera do Australii dotarła tylko jedna tódźt ${ }^{66}$.

Wypowiedzi premiera z 2015 r. wywołały wiele negatywnych komentarzy. Szczególnie szeroko komentowano jego wyrażone w Londynie stanowisko dotyczące europejskiego kryzysu migracyjnego. Abbott stwierdzil, że Europa powinna wziąć

${ }_{61}$ Australian Associated Press/BBC HARDtalk, Julia Gillard defends Australian immigration and asylum policy during her leadership - video, „The Guardian”, 18 VI 2015, [online] https://www.theguardian.com/world/video/2015/jun/18/julia-gillard-immigration-policy-video, 21 III 2018. Gillard mówiła także: To jest nasz kraj, nasza ziemia i nasz styl życia, z których pozwalamy wam korzystać. Więc jak już skończycie się skarżý, marudzić i kwestionować nasza flage, nasze zobowiązania i chrześcijańskie przekonania zachęcam was do skorzystania zjednego z naszych wolności - prawa do wyjechania. [...] Jeśli nie jesteście tutaj szczéśliwi, wyjedźcie. Nie zmuszaliśmy was do przybycia. Prosiliście o to. Więc zaakceptujcie kraj, który zaakceptowat was. B. M. Christensen, Hoax - Julia Gillard Tells Muslims to Adapt or Leave, Hoax-Slayer, 11 I 2013, [online] https://www.hoax-slayer.net/hoax-julia-gillard-tells-muslims-adapt-leave/, 28 III 2018.

62 Full transcript: Gillard's asylum policy... Żaden imigrant nie chce tam trafic. Recepta $z$ Antypodów...

Abbott unveils new asylum Policy, ABC News (Australia), 5 VII 2010, [online] https://www.youtube. $\mathrm{com} /$ watch?v=Zphp94SOE2c, 30 III 2018.

65 J. Donnison, Australia's asylum approach...

66 Tony Abbott's migrant speech condemned by Australian Catholics, BBC News, 29 X 2015, [online] http://www.bbc.com/news/world-australia-34664118, 30 III 2018. 
przykład z Australii i zamknąć granice dla nielegalnych imigrantów. Krytykował zachęcanie setek tysięcy ludzi do podejmowania niebezpiecznej podróży do Europy ${ }^{67}$, gdyż - jak podkreślif - jest to btędny altruizm. Odwołał się też do Johna Howarda i Rozwiązania pacyficznego, które zniwelowało problem pierwszej fali imigrantów. Drugą falę opanował sam Abbott w 2013 r. Jego zdaniem polityka ALP, czyli zakończenie Rozwiązania pacyficznego i zapraszanie imigrantów do Australii, przyczyniło się do odnowienia problemu nielegalnych migracji ${ }^{68}$. Najważniejszym elementem polityki migracyjnej rządu Abbotta była operacja Suwerenne granice (Operation Sovereign Borders). To dzięki niej premier zrealizował wszystkie obietnice wyborcze dotyczące boat people ${ }^{69}$. Taką wizję polityki imigracyjnej porównywano do pomysłów Donalda Trumpa i Nigela Farage' ${ }^{70}$.

Operacja Suwerenne granice to prowadzona przez wojsko operacja mająca zagwarantować bezpieczeństwo granic Australii i zwalczanie przemytu ludzi ${ }^{71}$. Boat people mieli być zawracani w kierunku Indonezji, skąd przybywało ich najwięcej ${ }^{72}$. Premier Abbott przyznał, że jego działania w zakresie nielegalnej imigracji wymagały użycia siły, ale nie przejmował się słowami krytyki, gdyż uznawał, że dzięki jego staraniom Australia jako jedyne państwo na świecie opanowała kryzys migracyjny ${ }^{73}$. Operacja okazała się sukcesem. Skutecznie ograniczono liczbę nielegalnych imigrantów, a także, zgodnie z oficjalnymi danymi, zażegnano problem zatonięć $c^{74}$. Na oficjalnej stronie operacji Suwerenne granice można znaleźć informację o udaremnionych próbach przedostania się na terytorium Australii ${ }^{75}$. Wyróżnia się na niej plakat przedstawiający zasmuconego imigranta, opatrzony napisem: Będziesz zawrócony do miejsca, z którego przybyteś. Inne informacje wskazują na brak sensu korzystania z usług przemytników, niebezpieczeństwo podróży i skuteczność australijskiej floty, która jest gotowa na pojawienie się imigrantów i odesłanie ich jak najdalej od granic Australiii ${ }^{76}$. Na jednej z podstron znajdują

67 Transcript: Tony Abbott's controversial speech at the Margaret Thatcher Lecture, „The Sydney Morning Herald", 28 X 2015, [online] https://www.smh.com.au/politics/federal/transcript-tony-abbotts-controversial-speech-at-the-margaret-thatcher-lecture-20151028-gkkg6p.html, 30 III 2018.

69 Tamże.

70 J. Donnison, Australia's asylum approach...

71 Operation Sovereign Borders (OSB), Department of Home Affairs, [online] http://osb.homeaffairs. gov.au/, 30 III 2018.

72 O. Laughland, Operation Sovereign Borders begins on Wednesday, „The Guardian”, 16 IX 2013, https:// www.theguardian.com/world/2013/sep/16/operation-sovereign-borders-begins-wednesday, 30 III 2018.

73 Transcript: Tony Abbott's controversial speech at the...

74 Operation Sovereign Borders (OSB)....

75 Operation Sovereign Borders (OSB), Department of Home Affairs, [online] http://osb.homeaffairs. gov.au/Outside-Australia, 31 III 2018.

76 Między innymi: Każdy, kto próbuje nielegalnie przyptyną́ do Australii, nie będzie osiedlony w Australii; Australia nigdy nie stanie się domem dla osób próbujących nielegalnie przedostać się droga morską na jej teren; Nie marnujcie swoich pieniędzy. Nie wierzcie w ktamstwa przemytników. Strona internetowa 
się informacje dla osób przebywających już na terytorium Australii. Rząd prosi, aby nie zachęcać swoich bliskich do przybywania do Australii w nielegalny sposób, ponieważ jest to niebezpieczna podróż, która nie zakończy się powodzeniem i nie jest warta narażania życia - rząd nie przewiduje wyjątków od prowadzonej polityki ${ }^{77}$. Na pytanie, czy Australia zmieni swoją radykalną politykę imigracyjną, premier Abbott odpowiedział w jednym z wywiadów po prostu: Nope, nope, nope $e^{78}$. Operacja Suwerenne granice miała zatrzymać wszystkich, którzy chcieli dostać się do Australii bez wizy ${ }^{79}$.

W 2013 r. Abbott stwierdzit, że dla Australijczyków priorytetem jest opanowanie przybywających drogą morską nielegalnych imigrantów. Panstwo musi podjąć nadzwyczajne środki - mówil. Po prawie dwóch latach rządów jego polityka odniosła sukces: Najbardziej przejmujące jest zatrzymanie naptywu osób nielegalnie przyptywajacych na todziach do Australii. My zatrzymalismy ten naptyw $w^{80}$. Prowadzenie "twardej polityki” i realizacja Operacji Suwerenne granice przyniosły oczekiwane rezultaty. Tony Abbott jest uważany za osobę, która zatrzymała kolejną falę nielegalnych imigrantów, któremu to problemowi nie potrafiły zaradzić rządy ALP ${ }^{81}$.

\subsection{Rządy Malcolma Turnbulla (2015-2018)}

W 2015 r. stanowisko przywódcy LP objął Malcolm Turnbull. W wielu kwestiach nie zgadzał się z Tonym Abbottem, jednak założenia polityki imigracyjnej pozostały bez zmian. Premier uważał, że „twarda polityka” wobec nielegalnej imigracji to jedyna możliwość przezwyciężenia problemu ${ }^{82}$. W przemówieniu wygłoszonym podczas 71 . sesji Zgromadzenia Ogólnego ONZ premier przypomniał, że społeczeństwo australijskie składa się przede wszystkim z imigrantów, którzy na przestrzeni 200 lat przybywali do Australii ${ }^{83}$. Otwartość na gości uznał za jedną z cech Australijczyków. W społeczeństwie ukształtowała się polityka wielokulturowości. Corocznie Australia przyjmowała do 190 tys. migrantów chcących osiedlić się na jej terytorium ${ }^{84}$. Turnbull konsekwentnie realizował założenia swojego poprzednika. Był świadom surowości polityki granicz-

Department of Home Affairs, [online] http://osb.homeaffairs.gov.au/en/Outside-Australia, 31 III 2018.

77 Operation Sovereign Borders (OSB), Department of Home Affairs, [online] http://osb.homeaffairs. gov.au/In-Australia, 31 III 2018.

78 J. Donnison, Australia's asylum approach...

79 T. Oriti, Former prime minster Julia Gillard stands by her hardline asylum seeker policies in rare interview, ABC News, 7 XI 2015, http://www.abc.net.au/news/2015-11-07/julia-gillard-defends-asylum-seeker-policies-in-rare-interview/6921156, 31 III 2018.

80 Film dokumentalny Chasing Asylum...

81 J. Donnison, Australia's asylum approach...

82 Speech to the United Nations General Assembly, oficjalna strona internetowa Malcolma Turnbulla, [online] https://www.malcolmturnbull.com.au/media/speech-to-the-united-nations-general-assembly, 1 IV 2018.

83 Tamże.

84 Tamże. 
nej, jednak rząd nie miał możliwości odwrotu. Odsyłanie łodzi przynosiło oczekiwane skutki, a tropienie przemytników ratowało życie tysięcy ludzi ${ }^{85}$. Polityka dotycząca zjawiska nielegalnej imigracji składała się według niego z trzech filarów: zawracania łodzi, działalności na morzu i przyznawania tymczasowej wizy ochronnej. Silna ochrona granic buduje pewność. Staby i niedziatajacy system prowadzi do przeciwnego skutku - thumaczył premier ${ }^{86}$. Pod koniec kwietnia $2017 \mathrm{r}$. minister imigracji i ochrony granic Peter Dutton ogłosił tysiąc dni bez dotarcia do Australii łodzi przemytników i trzy lata od ostatniej odnotowanej śmierci przy jej wybrzeżach. Przez trzy lata operacji Suwerenne granice udało się przechwycić 30 przemytników i 765 osób próbujących nielegalnie dostać się do Australii. Minister podkreślił też, że żaden nielegalny imigrant nie uzyska zgody na osiedlenie się w Australii ${ }^{87}$.

Pomimo wielu negatywnych opinii wywoływanych przez restrykcyjną politykę Australii latem 2017 r. Turnbull otrzymał nagrodę Disraeliego za najlepiej funkcjonujący, niedyskryminujący program dla migrantów, przyznaną przez brytyjski think tank Policy Exchange. Przyczyniła się ona do postrzegania Australii jako państwa stwarzającego wiele szans dla legalnych imigrantów ${ }^{88}$.

\section{OBOZY DLA IMIGRANTÓW PO ZAKOŃCZENIU ROZWIĄZANIA PACYFICZNEGO}

Pozostałością po Rozwiązaniu pacyficznym są w dalszym ciągu działające obozy przejściowe. Rząd Kevina Rudda zawierał umowy z państwami, do których mieli być wysyłani imigranci nieposiadający wizy, a rząd Tony’ego Abbotta zaczął umieszczać w nich imigrantów na czas nieokreślony. Mimo operacji Suwerenne granice, zakładającej zmniejszenie liczby łodzi dopływających do Australii, w obozach znajdowali się imigranci, którzy próbowali dopłynąć do Australii przed 2013 r.

Rząd Australii daje szansę na opuszczenie obozów przejściowych. Stara się nakłonić przebywające $\mathrm{w}$ nich osoby do dobrowolnego powrotu do ich ojczyzny. Wiele osób nie chce jednak wracać. Mimo złych warunków panujących w obozach pozostają w nich, oczekując na przyznanie im prawa do wjazdu do Australii. W 2016 r. rząd Turnbulla wprowadził zakaz osiedlania się w Australii nielegalnych imigrantów przy-

85 J. S. Carter, 'They will never come to Australia': Turnbull maintains tough stance on asylum seekers, ABC News, 23 IX 2015, [online] http://www.abc.net.au/radionational/programs/drive/prime-minister-malcolm-turnbull-tough-stance-on-asylum-seekers/6799610, 1 IV 2018.

86 Malcolm Turnbull, Liberal Party. Delivered at Sydney, June 26th, 2016, Election Speeches, 26 VI 2016, [online] https://electionspeeches.moadoph.gov.au/speeches/2016-malcolm-turnbull, 1 IV 2018.

871000 days of strong and secure borders, Ministerstwo Imigracji i Ochrony Granic, 23 IV 2017, [online] http://minister.homeaffairs.gov.au/peterdutton/Pages/1000-days-strong-secure-borders.aspx, 2 IV 2018.

88 Australian Associated Press, Malcolm Turnbull to be awarded UK prize for immigration program, „The Guardian”, 6 VII 2017, [online] https://www.theguardian.com/australia-news/2017/jul/07/ malcolm-turnbull-to-be-awarded-prize-for-immigration-program, 1 IV 2018. 
byłych w 2013 r., przebywających na Nauru i Manus. Prawo akceptacji przybywającego do Australii imigranta posiada minister imigracji i ochrony granic ${ }^{89}$. W 2016 r. Chitralekha Massey, przedstawicielka regionalna Biura Wysokiego Komisarza Narodów Zjednoczonych do spraw Praw Człowieka, stwierdziła, że działanie obozów na Nauru i Manus stanowi naruszenie i jest niekonieczne ${ }^{90}$. Natomiast zdaniem premiera Turnbulla australijski system ochrony granic jest najlepszy na świecie ${ }^{91}$.

Pozostający $\mathrm{w}$ obozach mają zapewnione minimum potrzebne do przeżycia. Przebywają w namiotach, często bez dostępu do elektryczności. Samo istnienie obozów i warunki w nich panujące wywołują sprzeciw społeczności międzynarodowej i organizacji zajmujących się prawami człowieka ${ }^{92} . \mathrm{Z}$ relacji wolontariuszki pracującej na Nauru wynikało, że przebywający tam ludzie nie posiadali ubrań i pożywienia, a nawet - mimo panujących tam wysokich temperatur - wody. Oprócz tego szerzyły się choroby (np. malaria) i infekcje ${ }^{93}$. Bezczynność, brak wiary i perspektyw prowadziły do problemów psychicznych i licznych prób samobójczych. Imigranci używali numerów przypisanych im w momencie wejścia do obozu. Zamiast imionami dzieci posługiwały się numerami z łodzi (boat ID), ponieważ w czasie pobytu w obozach ich jedynym dokumentem tożsamości był ten wydany w obozie ${ }^{94}$.

Metody te mają zagwarantować brak integracji imigrantów z otoczeniem. Zgodnie z prawem w obozach nielegalni imigranci mieli oczekiwać na rozpatrzenie wniosków azylowych nie dłużej niż sześć miesięcy. Jednak, najprawdopodobniej w celu zniechęcenia do osiedlenia się w Australii, w obozach znajdowały się osoby oczekujące na rozpatrzenie wniosku przez kilka lat ${ }^{95}$. Pomagający im wolontariusze mówili: $Z$ datem sobie sprawe, że dotartem do miejsca, $w$ którym nigdy nie powinienem się znaleźcíc. Złe traktowanie, a nawet poniżanie nielegalnych imigrantów, było sposobem na przekonanie ich oraz ich bliskich, aby nie przybywali do Australii ${ }^{97}$. Jak stwierdził jeden z australijskich dziennikarzy, udało się zatrzymać napływ nielegalnych imigrantów oraz, z pomocą wojska, działalność przemytników, jednak odbyło się to kosztem istnień ludzkich ${ }^{98}$.

89 D. Conifer, Manus Island, Nauru refugees to be banned from entering Australia, Malcolm Turnbull says, ABC News, 30 X 2016, [online] http://www.abc.net.au/news/2016-10-30/manus-nauru-refugees-asylum-seekers-to-be-banned-turnbull-says/7978228, 1 IV 2018.

90 P. Karp, Turnbull claims Australian border policies 'best in the world' despite widespread criticism, „The Guardian”, 17 IX 2016, [online] https://www.theguardian.com/australia-news/2016/sep/18/ malcolm-turnbull-australias-border-protection-policy-the-best-in-the-world, 1 IV 2018.

Tamże.

Żaden imigrant nie chce tam trafić. Recepta $z$ Antypodów...

Film dokumentalny Chasing Asylum...

Tamże.

Tamże; O. Laughland, 'It's freedom': Rohingya refugee reaches Florida after horror of Australian detention, „The Guardian”, 23 II 2018, [online] https://www.theguardian.com/australia-news/2018/ feb/23/rohingya-refugee-us-australia, 2 IV 2018.

Film dokumentalny Chasing Asylum...

O. Laughland, 'It's freedom': Rohingya refugee reaches Florida...

Film dokumentalny Chasing Asylum... 
Ze względu na panujące w obozach warunki na wyspach doszło do kilku incydentów. W 2013 r. na Nauru miały miejsce zamieszki. Starcia ze strażnikami i uzbrojonymi w maczety mieszkańcami wyspy zakończyły się pożarem obozu99. Natomiast w $2014 \mathrm{r}$. na Manus niezadowoleni z istnienia obozu mieszkańcy zaatakowali przebywających w nim imigrantów. W obawie o życie imigranci uciekli z ośrodka ${ }^{100}$. Tak wygląda wersja zdarzeń instytucji broniącej praw uchodźców. Inną przedstawił ówczesny minister imigracji i ochrony granic Scott Morrison (od sierpnia 2018 r. premier Australii). Zgodnie z oficjalnym oświadczeniem imigranci mieli sforsować ogrodzenie ośrodka, zetrzeć się z papuańską policją i uciec ${ }^{101}$.

Kurdyjski poeta i dziennikarz Behrouz Boochani przebywał w obozie na Manus przez cztery lata. Dzięki temu powstał film ukazujący obozowe życie. Boochani został aresztowany i oskarżony o donoszenie przeciwko wtadzom Manus. Kręcił filmy telefonem komórkowym mimo obowiązującego tam zakazu filmowania i robienia zdjęć102. Jego film obrazuje sposób traktowania ludzi w obozach (np. na Manus nie można było się uczyć czy pracować - można było tylko czekać). Sytuację imigrantów w obozach przedstawia także film, do którego powstania przyczynił się Behrouz Boochani Chauka, Please Tell Us the Time ${ }^{103}$. Obóz na wyspie Manus został zamknięty 31 października 2017 r. Sąd Najwyższy Papui-Nowej Gwinei stwierdził, że jego działanie jest niezgodne z konstytucją państwa. Przebywający na wyspie imigranci mieli zostać przesiedleni w inne miejsca na wyspie, przetransportowani m.in. na wyspę Nauru lub zawróceni do miejsca pochodzenia ${ }^{104}$. Jednak ze względu na to, że inne ośrodki przejściowe gwarantują jeszcze mniej bezpieczeństwa i panują w nich jeszcze gorsze warunki, przebywający na Manus imigranci odmówili opuszczenia obozu ${ }^{105}$, co w konsekwencji spowodowało przymusowe eksmisje ${ }^{106}$. Imigrantów rozlokowano w trzech obozach

99 Associated Press in Canberra, Nauru riot: 125 asylum seekers arrested, 21 VII 2013, „The Guardian”, [online] https://www.theguardian.com/world/2013/jul/21/nauru-riot-asylum-seekers-arrested, 2 IV 2018.

100 HO/PAP, Zamieszki w australijskim obozie dla uchodźców. Jedna osoba nie żyje, „Newsweek”, 18 II 2014, [online] http://www.newsweek.pl/swiat/zamieszki-australia-imigranci-newsweek-pl,artykuly,280945,1.html, 2 IV 2018.

101 Tamże.

102 Film dokumentalny Chasing Asylum...

103 Chauka, Please Tell Us the Time - Trailer - SFF 17, kanał Sydney Film Festival, 9 V 2017, [online] https://www.youtube.com/watch?v=EwaVMPYEzrA, 2 IV 2018. Zob. P. Bukalska, Gdy śpiew ptaka odmierza godziny, „Tygodnik Powszechny”, nr 6 z 4 II 2018, s. 46-48.

104 Polska Agencja Prasowa, Irańczyk powiesit się w ośrodku dla migrantów na Pacyfiku. UNHCR apeluje do wtadz Australii, Polsat News, 8 VIII 2017, [online] http://www.polsatnews.pl/wiadomosc/2017-08-08/iranczyk-powiesil-sie-w-osrodku-dla-migrantow-na-pacyfiku-unhcr-apeluje-do-wladz-australii/, 2 IV 2018.

105 L. Fox, Manus Island detention centre to permanently close today, 600 men refusing to leave, ABC News, 31 X 2017, [online] http://www.abc.net.au/news/2017-10-31/manus-island-detention-centre-to-close-at-5pm-today/9102768, 2 IV 2018.

106 Wyspa Manus: Australia skazuje uchodźców na życie w niepewności i niebezpieczeństwie, Amnesty International, 1 II 2018, [online] https://amnesty.org.pl/wyspa-manus-australia-skazuje-uchodzcow-na-zycie-w-niepewnosci-i-niebezpieczenstwie/, 2 IV 2018. 
znajdujących się w mieście Lorengau, znanym z niechęci do nielegalnych imigrantów. Trzy tygodnie po zamknięciu obozu na Manus - co oznacza prawie miesiąc życia bez prądu, żywności i wody - nadal przebywały w nim setki osób. Specjalne jednostki siłą starały się zmusić imigrantów do opuszczenia obozu ${ }^{107}$. Wielu mężczyzn nie chciało przenosić się do innego więziennego obozu (prison camp to określenie użyte przez Boochaniego ${ }^{108}$. Osoby przebywające w obozach tranzytowych w Lorengau obawiały się o swoje bezpieczeństwo w związku z aktami przemocy lokalnych mieszkańców wobec asylum seekers. Nowe ośrodki nie zapewniały bowiem nawet podstawowej ochrony, choćby w postaci ogrodzeń ${ }^{109}$.

Społeczność międzynarodowa stara się wpłynąć na rząd w Canberze, aby podjął działania naprawcze dotyczące obozów detencyjnych. Jednym z takich działań jest podpisanie z USA umowy, z której skorzystało 54 asylum seekers z wyspy Manus ${ }^{110}$, dającej możliwość osiedlenia się w USA australijskich imigrantów. Prezydent Donald Trump, pomimo zanegowania wynegocjowanej przez administrację Baracka Obamy umowy, zgodził się przyjąć 200 imigrantów (zamiast 1,2 tys.) ${ }^{111}$. Warunki gwarantowane przez USA są nieporównywalnie lepsze niż te panujące w australijskich obozach. Imigranci mają dostęp do wielu udogodnień, mogą podejmować pracę i uczęszczać do szkó $1^{112}$. W momencie ustalania umowy między Australią a USA premier Australii, tłumacząc prezydentowi Trumpowi zasady polityki imigracyjnej prowadzonej przez Canberrę, powiedział: Jeśli doptyniesz do Australii todzia, nawet jeśli myślimy, że jesteś najlepsza osoba na świecie, że jesteś geniuszem z Nagrodą Nobla, nie wpuścimy cię ${ }^{113}$. Zgodnie z doniesieniami medialnymi Trump miał odpowiedzieć na to: Jesteś gorszy $n i \dot{z} j a^{114}$.

Zamknięcie obozu na wyspie Manus nie oznacza poprawy sytuacji imigrantów. Rząd australijski zdecydował o utworzeniu kolejnego ośrodka przejściowego. Doszło do porozumienia z rządem Kambodży, który przyjął ofertę Australii. Umowa kambodżańska (the Cambodia Deal) pokazuje, że Australia jest w stanie wydać dużo pieniędzy, aby pozbyć się problemu migrantów (rząd zapłacił już $40 \mathrm{mln}$ AUD za otwarcie

107 H. Davidson, B. Doherty, Manus Island: PNG police move into detention centre and tell refugees to leave, „The Guardian”, 23 XI 2017, [online] https://www.theguardian.com/world/2017/nov/23/ manus-island-png-police-move-into-detention-centre-and-tell-refugees-to-leave?CMP=share_btn_ tw, 3 IV 2018.

108 B. Doherty, Second group of Manus Island refugees depart for US under resettlement deal, „The Guardian”, 23 XI 2017, [online] https://www.theguardian.com/australia-news/2017/nov/23/ refugee-and-journalist-behrouz-boochani-arrested-in-manus-as-squad-steps-in, 3 IV 2018.

109 Tamże.

110 B. Doherty, Second group of Manus Island refugees depart for US under resettlement deal, „The Guardian", 23 I 2018, [online] https://www.theguardian.com/australia-news/2018/jan/23/second-group-of-manus-island-refugees-depart-for-us-under-resettlement-deal, 3 IV 2018.

111 O. Laughland, It's freedom': Rohingya refugeereaches Florida...

112 Tamże.

113 P. Bukalska, Gdyśpiew ptaka odmierza...

114 Tamże. 
obozu $\left.^{115}\right)$. Jak stwierdził minister Dutton, rząd jest przygotowany na opłacanie obozów przejściowych przez dekady. Wyraził jednak nadzieję, że nie będzie to potrzebne - problem asylum seekers zniknie w momencie, kiedy potencjalni migranci wystraszą się australijskiej polityki migracyjnej do tego stopnia, że przestaną przybywać116. Wyrazem niezgody na taką politykę było złożenie pozwu grupowego przeciwko rządowi w Australii. Sprawa została wygrana przez stronę imigrantów. Australia miała wypłacić 70 mln AUD imigrantom, jednak nie wpłynęło to na zmianę jej stanowiska - obozy tranzytowe w Lorengau powstały i działają ${ }^{117}$. Premier Turnbull uważał zresztą, że Australia nie jest odpowiedzialna za 2 tys. przebywających w obozach imigrantów, ani za to, jakie panują w nich warunki, bowiem obozy należą do suwerennych państw, jakimi są Papua-Nowa Gwinea i Nauru. $Z$ tego wynikało więc, że w gruncie rzeczy to nie Australia przetrzymuje asylum seekers ${ }^{118}$.

W sierpniu 2018 r. doszło do zmiany rządu. Malcolma Turnbulla na stanowisku premiera zastąpił Scott Morrison, dotychczasowy minister skarbu ${ }^{119}$.

\section{PODSUMOWANIE}

W latach 2001-2018 r. prowadzono w Australii dwa rodzaje polityki imigracyjnej: mniej i bardziej restrykcyjną. Zależało to od tego, która z głównych partii sprawowała władzę: ALP czy LPA. Działania gabinetów Johna Howarda, Tony’ego Abbotta i Malcolma Turnbulla doprowadziły do ograniczenia napływu nielegalnych imigrantów do Australii. Rozwiązanie pacyficzne i operacja Suwerenne granice przyniosły oczekiwane skutki - wzbudziły strach przed niebezpieczną podróżą wśród potencjalnych nielegalnych imigrantów. Jednocześnie australijski rząd zachęcał turystów i potencjalnych pracowników do przybywania na teren Australii. Rządy Kevina Rudda i Julii Gillard oraz dramatyczna sytuacja wywołana napływem nielegalnych imigrantów doprowadzily do zmiany wizji polityki imigracyjnej Australijskiej Partii Pracy. Obecnie obie najważniejsze australijskie partie zapowiadają w swoich programach wyborczych prowadzenie restrykcyjnej polityki imigracyjnej. Sytuacja dotycząca istnienia obozów dla uchodźców w najbliższych latach nie ulegnie zmianie. Świadczą o tym podjęte działania mające zastąpić obóz na wyspie Manus przez inny (Lorengau). Zmiany nie zapo-

115 Film dokumentalny Chasing Asylum...

116 P. Karp, Turnbull claims Australian border policies...

117 B. Doherty, C. Wahlquist, Government to pay $\$ 70$ m damages to 1,905 Manus detainees in class action, „The Guardian”, 14 VI 2017, [online] https://www.theguardian.com/australia-news/2017/jun/14/ government-to-pay-damages-to-manus-island-detainees-in-class-action, 16 V 2018.

118 L. Taylor, Turnbull suggests Australia is not responsible for asylum seekers held offshore, „The Guardian”, 27 VI 2016, [online] https://www.theguardian.com/australia-news/2016/jun/28/turnbull-suggests-australia-is-not-responsible-for-asylum-seekers-held-offshore, 1 IV 2018.

119 M. Kruczkowska, Scott Morrison nowym premierem Australii. To autor twardej linii w polityce imigracyjnej, 24 VIII 2018, [online] http://wyborcza.pl/7,75399,23821408,scott-morrison-nowym-premierem-australii-to-autor-twardej.html, $20 \mathrm{~V} 2019$. 
wiada także objęcie stanowiska premiera przez Scotta Morrisona, uznawanego za jednego z twórców restrykcyjnej polityki imigracyjnej.

\section{BIBLIOGRAFIA}

\section{Literatura źródłowa:}

1000 days of strong and secure borders, Ministerstwo Imigracji i Ochrony Granic, 23 IV 2017, [online] http://minister.homeaffairs.gov.au/peterdutton/Pages/1000-days-strong-secure-borders.aspx.

10 years since apology for 'stolen' Aboriginal children, kanał Al Jazeera English, 13 II 2018, [online] https://www.youtube.com/watch?v=sbu6mcWAYck.

Abbott unveils new asylum Policy, ABC News (Australia), 5 VII 2010, [online] https://www. youtube.com/watch?v=Zphp94SOE2c.

Full transcript: Gillard's asylum policy speech, SBS News, 23 VIII 2013, [online] https://www. sbs.com.au/news/full-transcript-gillard-s-asylum-policy-speech.

John Howard's 2001 Election Policy Speech, kanał Malcolma Farnswortha, 22 II 2013, [online] https://www.youtube.com/watch?v=FxlunUpz-Nc\&t=876s.

Karlsen E., Phillips J., Koleth E., Seeking asylum: Australia's humanitarian program, strona internetowa parlamentu australijskiego, [online] http://www.aph.gov.au/binaries/library/pubs/ bn/sp/seekingasylum.pdf.

Malcolm Turnbull, Liberal Party. Delivered at Sydney, June 26th, 2016, Election Speeches, 26 VI 2016, [online] https://electionspeeches.moadoph.gov.au/speeches/2016-malcolmturnbull.

Phillips J., The 'Pacific Solution' revisited: a statistical guide to the asylum seeker caseloads on Nauru and Manus Island, strona internetowa parlamentu australijskiego, [online] https:// www.aph.gov.au/about_parliament/parliamentary_departments/parliamentary_library/ pubs/bn/2012-2013/pacificsolution.

Speech to the United Nations General Assembly, oficjalna strona internetowa Malcolma Turnbulla, [online] https://www.malcolmturnbull.com.au/media/speech-to-the-unitednations-general-assembly.

Strona internetowa Department of Home Affairs, [online] http://osb.homeaffairs.gov.au/en/ Outside-Australia.

Transcript: Tony Abbott's controversial speech at the Margaret Thatcher Lecture, „The Sydney Morning Herald", 28 X 2015, [online] https://www.smh.com.au/politics/federal/ transcript-tony-abbotts-controversial-speech-at-the-margaret-thatcher-lecture-20151028-gkkg6p.html.

\section{Literatura pomocnicza:}

- monografie i opracowania:

Adrift in the Pacific: the Implications of Australia's Pacific Refugee Solution, Oxfam, II 2002, [online] https://web.archive.org/web/20041014060834/http://www.oxfam.org.au/campaigns/ refugees/pacificsolution/. 
Filus A., Analiza restrykcyjnej polityki imigracyjnej Australii na przyktadzie sytuacji nielegalnych imigrantów, praca licencjacka, Kraków 2018.

Krakowiak M., Droga do wielokulturowości - polityka migracyjna Australii, „Biuletyn Migracyjny”, [online] http://biuletynmigracyjny.uw.edu.pl/33-s-luty-2012/droga-do-wielokulturowoscipolityka-migracyjna-australii.

Lencznarowicz J., Australia, Warszawa 2005.

Wrona M., Imigracja a gospodarka. Doświadczenia Australii, Warszawa 2016.

- artykuły prasowe:

Associated Press in Canberra, Nauru riot: 125 asylum seekers arrested, 21 VII 2013, „The Guardian", [online] https://www.theguardian.com/world/2013/jul/21/nauru-riot-asylumseekers-arrested.

Australian Associated Press, Malcolm Turnbull to be awarded UK prize for immigration program, „The Guardian”, 6 VII 2017, [online] https://www.theguardian.com/australia-news/2017/ jul/07/malcolm-turnbull-to-be-awarded-prize-for-immigration-program.

Australian Associated Press/BBC HARDtalk, Julia Gillard defends Australian immigration and asylum policy during her leadership - video, „The Guardian”, 18 VI 2015, [online] https:// www.theguardian.com/world/video/2015/jun/18/julia-gillard-immigration-policy-video.

Broom F., Has the 'Pacific Solution' solved anything in Australia?, Al-Jazeera, 3 IV 2014, [online] https://www.aljazeera.com/indepth/opinion/2014/03/pacific-solution-solved-austral201433113844238975.html.

Bukalska P., Gdy śpiew ptaka odmierza godziny, „Tygodnik Powszechny”, nr 6 z 4 II 2018.

Carter J. S., 'They will never come to Australia': Turnbull maintains tough stance on asylum seekers, ABC News, 23 IX 2015, [online] http://www.abc.net.au/radionational/programs/drive/ prime-minister-malcolm-turnbull-tough-stance-on-asylum-seekers/6799610.

Christensen B. M., Hoax - Julia Gillard tells Muslims to adapt or leave, Hoax-Slayer, 11 I 2013, [online] https://www.hoax-slayer.net/hoax-julia-gillard-tells-muslims-adapt-leave/.

Conifer D., Manus Island, Nauru refugees to be banned from entering Australia, Malcolm Turnbull says, ABC News, 30 X 2016, [online] http://www.abc.net.au/news/2016-10-30/ manus-nauru-refugees-asylum-seekers-to-be-banned-turnbull-says/7978228.

Davidson H., Doherty B., Manus Island: PNG police move into detention centre and tell refugees to leave, „The Guardian”, 23 XI 2017, [online] https://www.theguardian.com/world/2017/ nov/23/manus-island-png-police-move-into-detention-centre-and-tell-refugees-to-leave?CMP=share_btn_tw.

Doherty B., Second group of Manus Island refugees depart for US under resettlement deal, „The Guardian”, 23 XI 2017, [online] https://www.theguardian.com/australia-news/2017/ nov/23/refugee-and-journalist-behrouz-boochani-arrested-in-manus-as-squad-steps-in.

Doherty B., Second group of Manus Island refugees depart for US under resettlement deal, „The Guardian”, 23 I 2018, [online] https://www.theguardian.com/australia-news/2018/ $\mathrm{jan} / 23$ /second-group-of-manus-island-refugees-depart-for-us-under-resettlement-deal.

Doherty B., Wahlquist C., Government to pay $\$ 70 \mathrm{~m}$ damages to 1,905 Manus detainees in class action, „The Guardian”, 14 VI 2017, [online] https://www.theguardian.com/australianews/2017/jun/14/government-to-pay-damages-to-manus-island-detainees-in-class-action. 
Donnison J., Australia's asylum approach: Tough, proud and popular, BBC News, 18 VI 2015, [online] http://www.bbc.com/news/world-australia-33179049.

Fox L., Manus Island detention centre to permanently close today, 600 men refusing to leave, ABC News, 31 X 2017, [online] http://www.abc.net.au/news/2017-10-31/manusisland-detention-centre-to-close-at-5pm-today/9102768.

Hiscock S., Nauru and the Pacific Solution, „The Courier” 2002, no. 190, January-February.

HO/PAP, Zamieszki w australijskim obozie dla uchodźców. Jedna osoba nie żyje, „Newsweek”, 18 II 2014, [online] http://www.newsweek.pl/swiat/zamieszki-australia-imigranci-news week-pl,artykuly,280945,1.html.

Karp P., Turnbull claims Australian border policies 'best in the world' despite widespread criticism, „The Guardian”, 17 IX 2016, [online] https://www.theguardian.com/australia-news/2016/ sep/18/malcolm-turnbull-australias-border-protection-policy-the-best-in-the-world.

Kruczkowska, M., Scott Morrison nowym premierem Australii. To autor twardej linii w polityce imigracyjnej, 24 VIII 2018, [online] http://wyborcza.pl/7,75399,23821408,scott-morrison-nowym-premierem-australii-to-autor-twardej.html.

Laughland O., 'It's freedom': Rohingya refugee reaches Florida after horror of Australian detention, „The Guardian”, 23 II 2018, [online] https://www.theguardian.com/australia-news/2018/ feb/23/rohingya-refugee-us-australia.

Laughland O., Operation Sovereign Borders begins on Wednesday, „The Guardian”, 16 IX 2013, [online] https://www.theguardian.com/world/2013/sep/16/operation-sovereignborders-begins-wednesday.

Oriti T., Former prime minster Julia Gillard stands by her hardline asylum seeker policies in rare interview, ABC News, 7 XI 2015, [online] http://www.abc.net.au/news/2015-11-07/ julia-gillard-defends-asylum-seeker-policies-in-rare-interview/6921156.

Polska Agencja Prasowa, Irańczyk powiesit się w ośrodku dla migrantów na Pacyfiku. UNHCR apeluje do wtadz Australii, Polsat News, 8 VIII 2017, [online] http://www.polsatnews.pl/ wiadomosc/2017-08-08/iranczyk-powiesil-sie-w-osrodku-dla-migrantow-na-pacyfiku-unhcr-apeluje-do-wladz-australii/.

Reith P., Gillard can run, but she can't hide from Nauru backflip, ABC News, 26 XII 2011, [online] http://www.abc.net.au/news/2011-12-27/reith---gillard27s-half-arsed-nauru-backflip/3748020.

Taylor L., Turnbull suggests Australia is not responsible for asylum seekers held offshore, „The Guardian”, 27 VI 2016, [online] https://www.theguardian.com/australia-news/ 2016/jun/28/turnbull-suggests-australia-is-not-responsible-for-asylum-seekers-held-offshore.

Tony Abbott's migrant speech condemned by Australian Catholics, BBC News, 29 X 2015, [online] http://www.bbc.com/news/world-australia-34664118.

Wyspa Manus: Australia skazuje uchodźców na życie $w$ niepewności $i$ niebezpieczeństwie, Amnesty International, 1 II 2018, [online] https://amnesty.org.pl/wyspa-manus-australiaskazuje-uchodzcow-na-zycie-w-niepewnosci-i-niebezpieczenstwie/.

Zaden imigrant nie chce tam trafić. Recepta $z$ Antypodów na problem z uchodźcami, Forsal.pl, 8 II 2016, [online] http://forsal.pl/artykuly/921734,jak-australia-radzi-sobie-z-uchodzcami-czy-to-recepta-na-problemy-ue.html. 
- strony internetowe:

Strona internetowa wyliczająca odległości między państwami, http://www.dystans.org.

- filmy dokumentalne:

Chasing Asylum, reż. E. Orner, Australia 2016.

Chauka, Please Tell Us the Time - Trailer - SFF 17, kanał Sydney Film Festival, 9 V 2017, [online] https://www.youtube.com/watch?v=EwaVMPYEzrA.

Adam FILUS, student I roku studiów II stopnia na kierunku stosunki międzynarodowe (specjalność: studia nad rozwojem) w Instytucie Nauk Politycznych i Stosunków Międzynarodowych Uniwersytetu Jagiellońskiego. 